\title{
ANDRENA FLORIVAGA EVERSMANN, 1852 (HYMENOPTERA: APOIDEA: ANDRENIDAE) - A NEW BEE SPECIES OF THE GENUS ANDRENA IN POLAND
}

\author{
Józef Banaszak ${ }^{1 *}$, Ewelina Motyka ${ }^{1}$, Katarzyna Szczepko ${ }^{2}$ \\ ${ }^{1}$ Department of Ecology, Institute of Biology and Environmental Protection, \\ Kazimierz Wielki University, Ossolińskich Av. 12, 85-093 Bydgoszcz, Poland \\ ${ }^{2}$ Department of Didactics in Biology and Biodiversity Studies, \\ Faculty of Biology and Environmental Protection, \\ University of Łódź, Banacha St. 1/3, 90-237 Łódź, Poland \\ *corresponding author: lednica@ukw.edu.pl
}

Received 19 September 2012; accepted 10 April 2013

$$
\mathrm{S} \text { u m m a r y }
$$

The first record of Andrena florivaga Eversmann, 1852 is reported from Poland on the basis of specimens collected in the Kampinos National Park (Mazovian Lowland). Diagnosis, data on localities, biology, and general distribution of the species are provided. One female and five males were caught on a mowed fresh meadow and fallow fields with the use of water pan-traps (Moericke traps), during the 2003 - 2004 time period. The main morphological characteristics distinguishing Andrena florivaga from the very similar Andrena dorsalis Brullé, 1832 species and from the other species of the subgenus Lepidandrena are: in the case of females - the width of facial foveae and colouration of legs, and in the case of males - the length of the first flagellar segment, colouration of clypeus, and pubescence of gonostyles. Andrena florivaga can be found from France in the west, to Central Siberia (Baikal lake region) in the east, and Turkey in the south. Poland is the northernmost locality of the species.

Keywords: Hymenoptera, Apoidea: Andrenidae: Andrena: Lepidandrena, Andrena florivaga, new record, distribution, Poland.

\section{INTRODUCTION}

Lepidandrena Hedicke, 1933 is a Palearctic subgenus belonging to the genus Andrena. So far, 18 species from the Palearctic region were described (Gusenleitner and Schwarz, 2002). According to Banaszak (2000) only four species of subgenus Lepidandrena have been reported from Poland. Nevertheless, it should be emphasized that Dylewska (2000) suggested that it may be possible to find Andrena florivaga in the southeastern part of Poland. Andrena florivaga was originally described by Eversmann (1852). After Eversmann, additional information about this species was provided by Blüthgen (1914), S toeckhert (1930),
Osytshnjuk (1977), Riemann (1985), Dylewska (1987), Schmid-Egger and Scheuchl (1997), Osytshnjuk et al. (2008). Blüthgen (1914) was the first author who described a male of Andrena molhusina Blüthgen, 1914 (synonym of A. florivaga). Illustrations of the morphological details of $A$. florivaga can be found in the papers of Riemann (1985), Dylewska (1987), Schmid-Egger and Scheuchl (1997) and Osytshnjuk et al. (2008).

This paper presents the diagnosis, data on biology, general distribution, and Polish localities of Andrena florivaga Eversmann, 1852 - a species of the wild bee new to Poland. 


\section{MATERIAL AND METHODS}

\section{Material examined and localities}

Mazovian Lowland. DC59, Pieklice: 29.05.2003 - 19, a mowed (once a year) fresh meadow; 01.05.2004 - 10ิ, 1-year old fallow field, after potatoes; 01.05.2004 - 10, 1-year old fallow field, after wheat.

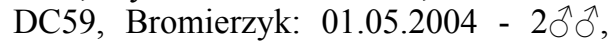
4-year old fallow field, after oat and potatoes; 23.04.2004 - 1ð, 3-year old fallow field, after oat and beets.

All specimens were collected by $\mathrm{K}$. Szczepko in the Kampinos National Park with the use of water pan-traps. The materials are deposited in the authors' collection.

\section{RESULTS}

Andrena florivaga Eversmann, 1852 Synonym: Andrena molhusina Blüthgen, 1914

\section{Diagnosis}

The female can be distinguished from the very similar Andrena dorsalis Brullé, 1832 species by the following characters: facial foveae occupying more than $1 / 2$ ocellocular distance, hind tibiae, medial and hind tarsi orange. The male can be separated from A. dorsalis by the following characters: the first flagellar segment is

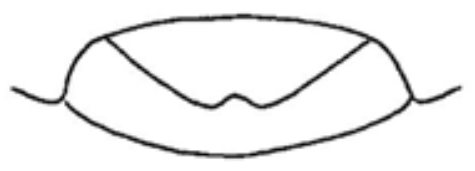

a

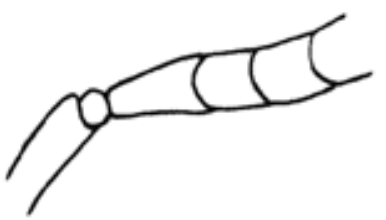

C shorter than the combined length of $2^{\text {nd }}$ and $3^{\text {rd }}$ segments, the clypeus is white, with black, small maculae on each side of the basal part, gonostyles have dense, long hairs. Those morphological traits allow Andrena florivaga to be distinguished from other bee species of the subgenus Lepidandrena in Poland.

\section{Redescription}

\section{Female.}

Body length: 9 - $10 \mathrm{~mm}$. Structure: Basal area of labrum trapezoidal (Fig. 1a). Clypeus shiny, finely shagreened, irregularly punctured. Facial foveae reach somewhat below antennal sockets, broad in upper part and narrow in lower part, occupying more than $1 / 2$ ocellocular distance (Fig. 1b). Mesoscutum and scutellum shagreened, shiny - especially in the middle, deeply punctured; punctures scattered in the middle. Metasomal terga 2 - 4 are shiny, densely, regularly and deeply punctured; marginal zones of those terga equal to $1 / 3$ of tergal length, and are finely punctured.

Colouration: Body black. Wings orangish-brown. Stigma orange. Marginal zones of terga reddish. Hind tibiae, medial and hind tarsi orange.

Pubescence: Head and mesosoma with short and dense, whitish hairs. Propodeal

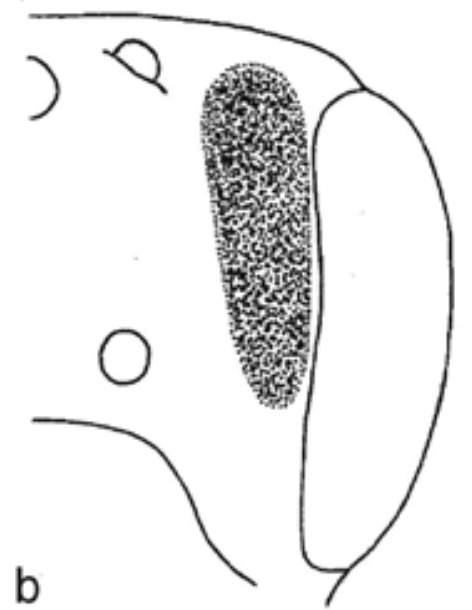

Fig. 1. Andrena florivaga Eversmann, 1852, female: basal area of labrum (a), facial fovea (b), after Osytshnjuk et al. (2008), modified; male: $1^{\text {st }}-3^{\text {rd }}$ flagellar segments (c), after Osytshnjuk et al. (2008). 
corbicula and trochanteral flocculus with long, whitish hairs. Tibial scopa dense, scopal hairs are a light golden colour and long. Metasomal terga 2 - 4 with broad apical fasciae of dense, long, white hairs, interrupted on tergum 2. Prepygidial fimbria golden colour.

\section{Male}

Body length: 8 - 9 mm. Structure: Microsculpture of clypeus similar to female, but it is shinier and also more sparsely punctured. The first flagellar segment shorter than the combined length of $2^{\text {nd }}$ and $3^{\text {rd }}$ segments (Fig. 1c). Hind tibiae, middle, and hind tarsi orange. Mesoscutum, scutellum, and metasomal terga deeply punctured. Gonocoxites with well-developed dorsal lobes, penis valvae broader basally, narrow apically, gonostyles elongated, with dense, long hairs, moderately dilated distally and proximally (Fig. 2a). Sternum 8 as shown in Fig. $2 b$.

Colouration: Body colouration as in female, but clypeus white, with black, small maculae.

Pubescence: Body pubescence as in female, but head and clypeus with longer, denser, white hairs. Metasomal terga 1 - 5 with apical fasciae of sparse, long, white hairs, interrupted on terga $1-3$, occasionally on tergum 4. Sterna 2 - 5 with apical fasciae not interrupted in the middle; sternum 2 with apical fimbria of short, sparse hairs in contradistinction to sterna 3 - 5, which have long, dense apical fimbriae.

\section{Distribution}

A. florivaga is distributed from France in the west, through: Germany, the European part of the Russian Federation, the Caucasus, and Central Kazakhstan, to Central Siberia (Baikal lake region) in the east. It is distributed from Turkey in the south, through: the Balkans, Austria, Bohemia, Moravia and Slovakia (Blüthgen, 1914; 1924; Kocourek, 1966; Warncke, 1974; Warncke et al., 1974; Gogala, 1991; 1994; 1999; Schwarz et al., 1996; Bogusch et al., 2007). Poland is the northernmost locality of the species (Fig. 3).

\section{Remarks}

The morphological characteristics of female and males collected in Poland, match the original description given by Eversmann (1852), Osytshnjuk (1977), Gusenleitner and Schwarz (2002), and Osytshnjuk et al. (2008). Blüthgen (1924) gave the information about the

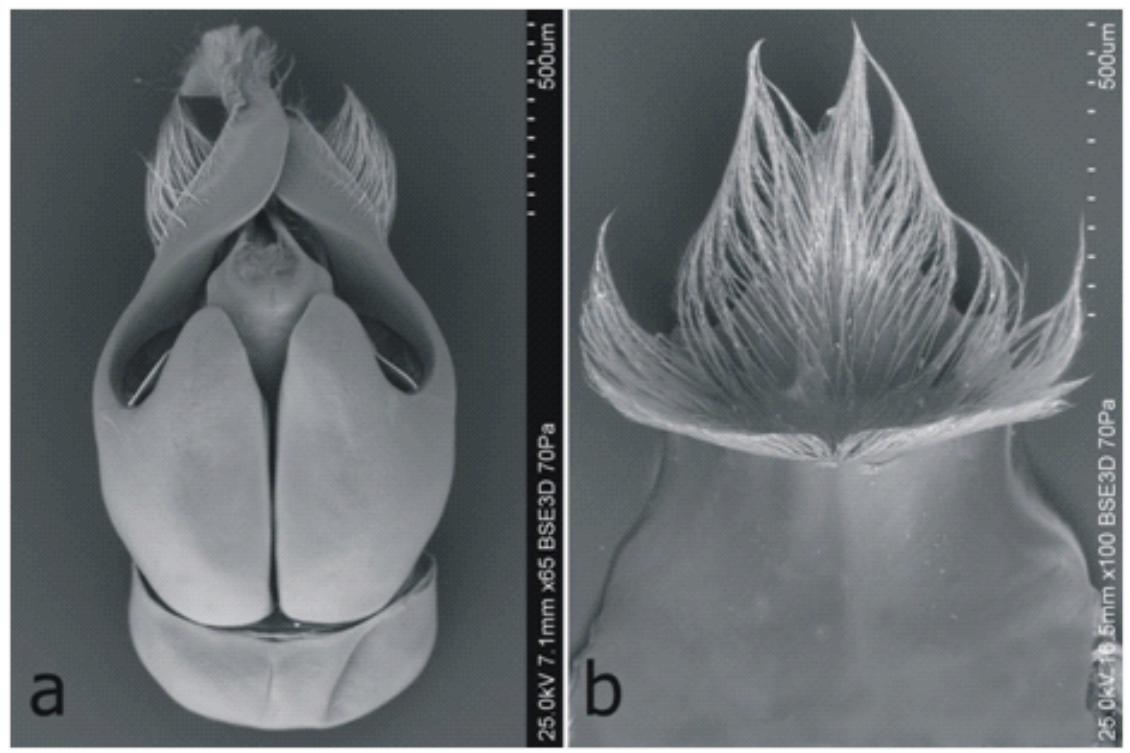

Fig. 2. Andrena florivaga Eversmann, 1852, male: genital capsule (a) and sternum 8 (b). 


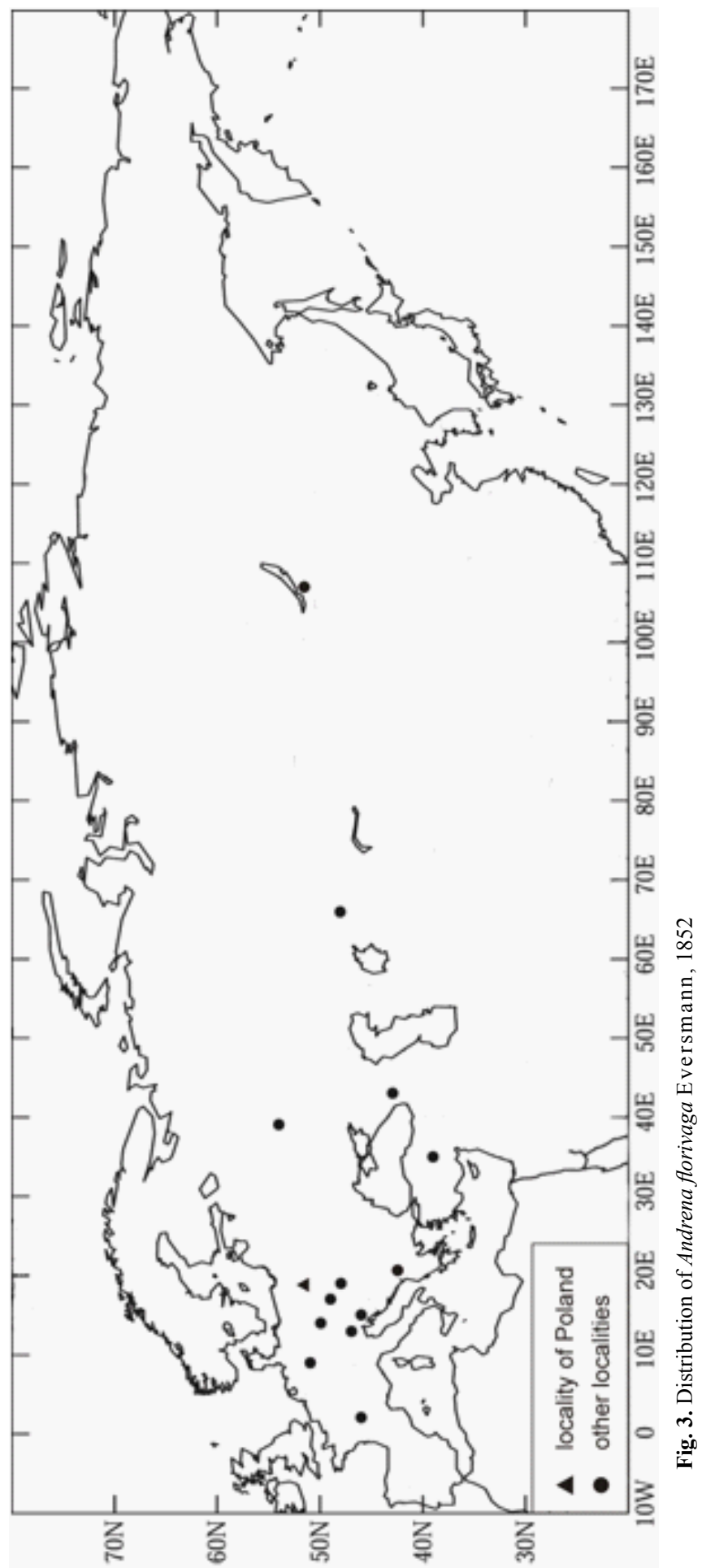


general distribution of $A$. florivaga and also listed the Balkans without giving any specific locality. Later Warncke (1965) quoted the distribution data of the bee from Blüthgen's paper, but listed Greece which was surely an overinterpretation of the previously published information. We decided to ignore Warncke's doubtful data.

\section{Biology}

Univoltine. Flight season: from May to June, occasionally late April. Polylectic. The females visit flowers of the Asteraceae, Brassicaceae, Liliaceae, Ranunculaceae, Rosaceae, and Scrophulariaceae. This taxon belongs to the local steppe species. Andrena florivaga prefers xeric biotopes of the plains and mountains and was recorded at an altitude of $2000 \mathrm{~m}$ (Talysh, Nakhichevan) (Osytshnjuk et al., 2008). The species nests in excavated burrows in the ground (Schmid-Egger et al., 1995). $A$. florivaga is a host of the cleptoparasitic bee Nomada guttulata Schenck, 1861 (Kocourek, 1966).

\section{ACKNOWLEDGMENTS}

We are grateful to Jan Boratyński for making the scan of the genital capsule and sternum 8 of the male.

\section{REFERENCES}

Banaszak J. (2000) - A checklist of the bee species (Hymenoptera, Apoidea) of Poland, with remarks on their taxonomy and zoogeography: revised version. Fragm. Faun., 43(14): 135-193.

Blüthgen P. (1914) - Abweichende Färbungen bei einigen paläarktischen Bienen. Eine neue Andrena (Andrena molhusina nov. spec.) (Hym.). Ent. Mitt., 3: 153-156.

Blüthgen P. (1924) - Über Andrena dobrowlanensis Nosk., A. freya Strand und einige andere Sandbienenarten (Hym. Apidae). Dtsch. Ent. Z., 2: 180-183.
Bogusch P., Straka J., Kment P. (2007) - Annotated checklist of the Aculeata (Hymenoptera) of the Czech Republic and Slovakia. Acta Ent. Mus. Nat. Pragae, Suppl. 11: 241-299.

Dylewska M. (1987) - Die Gattung Andrena Fabricius (Andrenidae, Apoidea) in Nordund Mitteleuropa. Acta Zool. Cracov., 30(12): 359-708.

Dylewska M. (2000) - Pszczołowate - Apidae. Podrodzina - Andreninae. Błonkówki Hymenoptera. Klucze do oznaczania owadów Polski [Apoidea. Subfamily Adreninae. Hymenoptera. Keys to identification of Polish insects], vol. 24, part 68d. Polskie Towarzystwo Entomologiczne, Torun, p. 152.

Eversmann E. (1852) - Fauna Hymenopterologica Volgo-Uralensis. Bull. Soc. Nat. Moscou., 25(3): 1-137.

Gogala A. (1991) - Contribution to the Knowledge of the Bee Fauna of Slovenia: (Hymenoptera: Apidae). Scopolia, 25: 1-33.

Gogala A. (1994) - Contribution to the Knowledge of the Bee Fauna of Slovenia II: (Hymenoptera: Apidae). Scopolia, 31: 1-40.

Gogala A. (1999) - Bee Fauna of Slovenia: Checklist of Species (Hymenoptera: Apoidea). Scopolia, 42: 1-79.

Gusenleitner F., Schwarz M. (2002) Weltweite Checkliste der Bienengattung Andrena mit Bemerkungen und Ergänzungen $\mathrm{zu}$ paläarktischen Arten (Hymenoptera, Apidae, Andreninae, Andrena). Entomofauna, Suppl. 12, p. 1280.

Kocourek M. (1966) - Prodromus der Hymenopteren der Tschechoslowakei. Pars 9: Apoidea, 1. Acta Faun. Ent. Mus. Nat. Pragae, 12, Suppl. 2: 1-122.

Osytshnjuk A. Z. (1977) - Fauna of Ukraine. Vol. 12. Bees [Apoidea]. No. 5. Family Andrenidae. Naukova Dumka, Kiev, p. 328.

Osytshnjuk A. Z., Romasenko L., Banaszak J., Motyka E. (2008) Andreninae of the Central and Eastern Palearctic. Part 2. Polish Entomological Monographs, vol. 5. Polish Entomological Society, Poznań, Bydgoszcz, p. 233. 
Riemann H. (1985) - Beitrag zur Chrysididen und Aculeatenfauna des westlichen Nordeutschlands (Hymenoptera). Drosera, 85(1): 17-28.

Schmid-Egger C., Scheuchl E. (1997) - Illustrierte Bestimmungstabellen der Wildbienen Deutschlands und Österreichs unter Berücksichtigung der Arten der Schweiz. Band III: Schlüssel der Arten der Familie Andrenidae, Selbstver-lag, Velden, p. 180.

Schmid-Egger C., Risch S., Niehuis O. (1995) - Fauna und Flora in Rheinland Pfalz. Zeitschrift für Naturschutz, Beiheft 16. Die Wildbienen und Wespen in Rheinland-Pfalz (Hymenoptera, Aculeata). Verbreitung, Ökologie und Gefährdungssituation. Gesellschaft für Naturschutz und Ornithologie. Reinland-Pfalz e.V. (GNOR), Landau, p. 296.
Schwarz M., Gusenleitner F., Westrich P., Dathe H. H. (1996) Katalog der Bienen Österreichs, Deutschlands und der Schweiz (Hymenoptera, Apidae). Entomofauna, Suppl. 8: 1-398.

Stoeckhert E. (1930) - Andrena F., in: Schmiedeknecht O. (Ed.) Die Hymenopteren Nord- und Mitteleuropas mit Einschluss von England, Südschweitz, Südtirol und Ungarn nach ihren und zum grossen Teil auch nach ihren Arten analytisch bearbeitet, Verlag von Gustav Fischer, Jena, pp. 897-986.

Warncke K. (1965) - Beitrag zur Kenntnis der Bienengattung Andrena Fabricius in Griechenland. Beitr. Ent., 15(1-2): 27-76.

Warncke K. (1974) - Die Sandbienen der Türkei (Hymenoptera, Apoidea, Andrena). Teil A. Mitt. Münch. Ent. Ges., 64: 81-116.

Warncke K., Desmier de Chenon R., Leclercq J. (1974) - Hymenoptera Apoidea Andrenidae: Andrena F., in: Atlas Provisoire des Insectes de France 1-9. Maps 1-177.

\title{
ANDRENA FLORIVAGA EVERSMANN, 1852 (HYMENOPTERA: APOIDEA: ANDRENIDAE) - NOWY GATUNEK PSZCZOLY Z RODZAJU ANDRENA W POLSCE
}

\author{
Banaszak J., Motyka E., SzczepkoK. \\ S t r e s z c z e n i e
}

W oparciu o materiał zebrany w Kampinoskim Parku Narodowym (Nizina Mazowiecka) zaprezentowano rzadki gatunek Andrena florivaga Eversmann, 1852, dotychczas nie wykazywany z Polski. W artykule przedstawiono diagnozę, stanowiska, biologię i ogólne rozmieszczenie tego gatunku. Sześć osobników (jedną samicę i pięć samców) odłowiono na koszonej łące świeżej i na odłogach za pomocą pułapek Moerickego (,żółtych misek”), w latach 2003-2004. Głównymi cechami morfologicznymi pozwalającymi odróżnić Andrena florivaga od bardzo podobnego gatunku Andrena dorsalis Brullé, 1832 i od innych gatunków z podrodzaju Lepidandrena są: w przypadku samicy - szerokość zagłębień twarzowych i ubarwienie odnóży, w przypadku samca - długość pierwszego członu czułka, barwa nadustka oraz owłosienie gonostyli. Andrena florivaga występuje od Francji - na zachodzie, po Centralną Syberię (region jeziora Bajkał) - na wschodzie, oraz po Turcję - na południu. Na północy najbardziej wysuniętym stanowiskiem tego gatunku jest Polska.

Slowa kluczowe: Hymenoptera, Apoidea: Andrenidae: Andrena: Lepidandrena, Andrena florivaga, nowy gatunek, rozmieszczenie, Polska. 